\title{
The impact of deforestation and pasture abandonment on soil properties in the wet tropics of Australia
}

\author{
V. Rasiah ${ }^{\mathrm{a}, *}$, S.K. Florentine ${ }^{\mathrm{b}, 1}$, B.L. Williams ${ }^{\mathrm{b}}$, M.E. Westbrooke ${ }^{1}$ \\ ${ }^{a}$ Department of Natural Resources and Mines, 28 Peters Street, Mareeba, QLD 4880, Australia \\ ${ }^{\mathrm{b}}$ Centre for Rainforest Studies, School for Field Studies, Yungaburra, QLD 4872, Australia
}

* Corresponding author. Tel.: +61-7-4048-4718; fax: +61-7-4092-3593.

E-mail address: rasiah_v@nrm.qld.gov.au (V. Rasiah).

${ }^{1}$ Present address: School of Science and Engineering, University of Ballarat, PO Box 663, Vic 3350, Australia. 


\section{Introduction}

Forest regrowth in abandoned unproductive pasturelands, which were previously under forest, is one of the options considered appropriate (i) for reversing the trends in global warming (Berger, 1990), (ii) to regain, at least partially, the loss in biodiversity (Berger, 1990), and (iii) for environmental sustainability (Keenan et al., 1998; Berger, 1990). Throughout the tropics, and more specifically in the Northeast Queensland (NEQ) wet tropical region of Australia, extensive forested ecosystems have been deforested for sugarcane, banana, and pasture, both for dairy and beef cattle production (Tucker, 2000; Tucker and Murphy, 1997; Aide et al., 1995; Crome and Bentrupperbaumer, 1993; Hecht, 1993). In the NEQ wet tropics the clearing of woody vegetation for pasture, intensive cropping, and urban development is still continuing (Brodie, 2003; Productive Commission Report, 2003). For example, in the Herbert catchment of the NEQ wet tropics the rate of clearing was $18.5 \mathrm{~km}^{2} /$ year, for pasture and cropping, between 1991 and 1995 compared to $0.33 \mathrm{~km}^{2} /$ year for urban development. During the same period, the new regrowth rate was only 0.54 $\mathrm{km}^{2} /$ year. It seems much faster regrowth is required for general ecosystem sustainability.

Approximately $52 \%$ of the land in the NEQ wet tropics is under pasture (Brodie, 2003; Productive Commission Report, 2003). However, due to changing economic considerations or invasion by unpalatable grasses and/or soil degradation due to loss in fertility, increases in acidity, salinity, Al-toxicity, and/ or erosion from steep slopes, some of the pasturelands have been abandoned in the NEQ wet tropics and elsewhere (Aide et al., 1995; Goosem and Tucker, 1995; Uhl et al., 1988; Brown and Lugo, 1990). The anticipation during abandonment was that this abandoned pastureland may become secondary forests over time and this may help in restoring, at least partially, the biodiversity lost after deforestation and to sustain the general ecosystem health (Brown and Lugo, 1990; Buschbacher, 1986; Buschbacher et al., 1984).

Though reliable information on abandonment is not available, the regrowth rate $\left(0.54 \mathrm{~km}^{2} /\right.$ year $)$ suggests this rate is very slow compared to clearing (18.5 $\mathrm{km}^{2} /$ year) and the reason(s) for slow regrowth is not well known. In this regard an understanding of the factors that control regrowth after abandonment is essential to accelerate regrowth (Aide and Cavelier, 1994; Uhl, 1987; Uhl et al., 1988). Several factors may be controlling regrowth simultaneously, but it is difficult, if not impossible, to investigate the integrated impact of all these variables. Because soil is the medium on which primary or secondary forest seed germinate, survive and establish stand, an understanding of the changes in soil properties before clearing, under grazed pasture, and under long-term abandoned pasture, may help in guiding forest regrowth or reforestation. However, such information in general, and in particular for the NEQ wet tropics, is scarce (Johnston, 1992; Reiners et al., 1994).

The changes that occurred elsewhere after deforestation and subsequent cropping are decreases in plant available nutrients (Lu et al., 2002; Keenan et al., 1998; Webb et al., 1997; Sparling et al., 1994; Maggs and Hewett, 1990, 1993), decreases in microbial activity (Kiese et al., 2002; Sahani and Behera, 2001;Sparling et al., 1994; Maggs and Hewett, 1990), increases in bulk density, soil erosion, and runoff (Rasiah and Kay, 1995; Jusoff, 1989), and decreases in porosity, infiltration and water-holding capacity ( $\mathrm{Lu}$ et al., 2002; Sahani and Behera, 2001; Reiners et al., 1994; Sparling et al., 1994). The aforementioned studies indicate that deforestation and the subsequent land use for crop production, including pasture, in general led to the deterioration in soil chemical, physical, and biological properties. However, when some of these degraded soil were brought under wellmanaged pasture, significant improvements in degraded properties occurred after the introduction of pasture (Rasiah and Kay, 1994a,b, 1995; Baldock and Kay, 1987; Tisadall and Oades, 1980). It is, however, not known whether similar improvements would occur under abandoned pasture, which was not managed properly even before abandonment. Such information is required for several reasons. First, if natural forest regrowth is poor after abandonment for substantially long period of time, then the information on soil properties may help, at least partially, to identify the factor(s) controlling regrowth or reestablishment. Second, this information may be useful to assess the resiliency of soils in different tropical environment to recover from man induced changes and finally to determine the time required for substantial recovery to occur. The latter information is crucial if monetary 
benefits are considered for abandonment and subsequent reforestation. Thus, the objective of this study was to assess the impact of deforestation on selected soil physico-chemical properties from (i) an abandoned pastureland and (ii) a recently planted rainforest (PRF), planted in the abandoned pastureland.

\section{Materials and methods}

\subsection{Study site}

The study site is located in the Yungaburra rainforest area of the NEQ wet tropics, Australia (17 15' $\left.19^{\prime \prime} \mathrm{S}, 14530^{\prime} 59^{\prime \prime} \mathrm{E}\right)$. More specifically, the experimental plot is at the Centre for Rainforest Studies (CRS), School for Field Studies of USA, property, which is approximately 65 ha. The elevation is approximately $780 \mathrm{~m}$ above sea level, the climate is typical tropical with an average annual rainfall of $1700 \mathrm{~mm}$, most of it received during December to May. The experimental plot is located on the North West boundary of the CRS abandoned pastureland. The plot site was clear-felled for beef cattle grazing approximately 70 years ago and was not fertilized during the 30-year grazing period after deforestation. Before the clearing, this site was dominated by complex mesophyll-type forest trees (Tracey, 1982). During the 40-year abandonment, however, natural forest regrowth of mesophyll type forest tress (Tracey, 1982) did not occur until 2002. The site is now invaded by a number of grass weeds species, particularly Imperata cylindrica, Melinis minutiflora, and Panicum maximum.

\subsection{Experimental design and forest species used}

The experimental site was divided into 10 plots of equal size of $17 \times 11 \mathrm{~m}$. In field experiments involving forest species, large plots are required for obvious space requirement by forest species. This imposed a limitation on the number of replications; therefore, only two replications were feasible in a completely randomised block design experiment. In each plot, exclusive of the control, 63 tropical rainforest seedlings were planted in 1992. In Treatment 1 Omalanthus novoguineensis and in Treatment 2, 23 O. novo-guineensis and 8 primary promoter species $(5$ from each of
Elaeocarpus angustifolius, Cryptocarya triplinervis, Eurochinus falcata, Guioa acutifolia, Terminalia sericocarpa, Pilidiostigma tropicum, Castanospermum alphandii, Acronychia acidula species) were planted. In Treatment 3, O. novo-guineensis was replaced by equal number of Alphitonia petriei and other 8 primary promoter species equal to that in $2 \mathrm{~A}$ and $2 \mathrm{~B}$. In Treatment 4, we combined 7 middle phase canopy species (3 from each of Agathis robusta, Flindersia bourjotiana, Cardwellia sublimis, Flindersia pimenteliana, Brachychiton acerifolius, Melicope elleryana and Symplocos cochinchinensis), 10 primary promoter species (2 from each of $O$. novo-guineensis, E. angustifolius, C. triplinervis, E. falcata, G. acutifolia, T. sericocarpa, P. tropicum, C. alphandii, A. acidula, and $A$. petriei) and 7 mature phase canopy species (3 from each of Cinnamomum laubatii, Argyrodendron peralatum, Prunus turnerana, Cryptocarya hypospodia, Syzygium papyraceum, Syzygium wesa, and Toona ciliata). The treatments (1 to 4) containing native tropical rainforest species will hereafter will be referred to as planted rainforest (PRF). Treatment 5 is the abandoned pasture (control), where there was substantial invaded weed species. Thirty grams of a commercial fertilizer containing $\mathrm{N}$ and $\mathrm{P}$ of unknown proportion and forms was mixed into the soil before the seedlings were planted.

From the East and West borders of the plot the land is sloping at $10-12 \%$ toward creeks, which are $\approx 300-400 \mathrm{~m}$ away from the $\mathrm{E}$ and $\mathrm{W}$ borders. From $\mathrm{N}$ to $\mathrm{S}$ the experimental site is sloping at $\approx 10-12 \%$ and the Southern border is $\approx 300 \mathrm{~m}$ away from another creek. In brief, the experimental plot was on a ridge sloping towards the creek. In this study, we use the nearby native rainforest as the background against which we assess the changes in soil properties under the abandoned pasture and PRF treatments.

In the absence of rainforest in the vicinity of abandoned pasture site, we selected the closest possible rainforest, which was $\approx 500 \mathrm{~m}$ away from the eastern border of the plot. The rainforest faces the plot from the other side of creek, which was $\approx 300 \mathrm{~m}$ away from the eastern border of the plot. The rainforest is on a ridge with similar topography and morphology as the experimental plot. The soil in the plots and the rainforest belongs to the same Ferrosol soil order (Isbell, 1994; Gillman and Abel, 1987; Gillman and Sinclair, 1987; Murtha, 1986). This soil 
is red to brown, acidic, well structured clay formed on basalt, with deep profiles ranging from 1 to $>10 \mathrm{~m}$. The clay content is relatively high ( $62 \%$ to $68 \%)$, and the silt and organic matter contents range from $21 \%$ to $16 \%$ and $2.0 \%$ to $0.6 \%$, respectively. Thus, with the aforementioned similarities between the rainforest and the plot site, we propose to use the paired $t$-test for comparison of soil properties between the two sites.

\subsection{Soil properties}

In this paper, we present the data relating to selected properties of the soil that were collected in July 2001 from the PRF, $\approx 10$ years old, the abandoned pasture plot $\approx 40$ years old, and from the undisturbed rainforest.

Three random soil cores, using a $5-\mathrm{cm}$ diameter corer, were taken up to $15-\mathrm{cm}$ depth in July 2001, from each plot for nitrate- $\mathrm{N}$, ammonium- $\mathrm{N}$, total $\mathrm{N}$, electrical conductivity, $\mathrm{pH}$ (in water and calcium chloride), exchangeable $\mathrm{Ca}, \mathrm{Mg}, \mathrm{Na}, \mathrm{K}$, and $\mathrm{Al}$, total organic $\mathrm{C}$, and labile-C determination. Another six cores from each plot were taken along the diagonals, three from each diagonal, of each plot for dry bulk density determination (core volume $=209.35 \mathrm{ml}$ ). Soil samples from the nearby rainforest were taken along the N-to-S line from three locations that were $50 \mathrm{~m}$ apart. The N-to-S line was approximately parallel to plot length. Three cores were taken from each location for soil property analysis and three cores for bulk density determination.

\subsection{Procedures used}

Soil sample from each plot was air-dried and subsamples $(<2 \mathrm{~mm})$ from each core of each plot was analyzed, for each one of the soil property mentioned elsewhere, in the laboratory. Ammonium-N and nitrate-N determinations were conducted using Lachat Flow analyzer method (Searle, 1984). Total N, total soil organic $\mathrm{C}$ (SOC), labile-C, $\mathrm{pH}$ (in $\mathrm{H}_{2} \mathrm{O}$ and $\mathrm{CaCl}_{2}$ ), electrical conductivity, and exchangeable $\mathrm{K}$, $\mathrm{Na}, \mathrm{Ca}, \mathrm{Mg}$, and $\mathrm{Al}$ determinations were carried out following the procedures described by Rayment and Higgins (1992). Labile-C concentration was determined at two dilutions, 33.3 and $333 \mathrm{mmol}$, of potassium permanganate (Blair et al., 1995). The fraction determined at low dilution is referred to as
labile-C1 and other labile-C2. Dry bulk density, using the oven-dry method, was determined for each one of the cores taken from each plot and from each location under the rainforest.

\section{Statistical analysis}

The data were subjected to Waller-Duncan multiple range test for mean separation among treatments (5) for a given property and the paired $t$-test between rainforest and a given treatment for a given soil property. Simple correlation and stepwise multivariable regression were performed on the data pooled across treatments and rainforest. The SAS (1991) software package was used for all the statistical analyzes.

\section{Results and discussion}

\subsection{Nitrogen}

Under the abandoned pasture and PRF, nitrate-N content ranged from 3.0 to $7.0 \mathrm{mg} / \mathrm{kg}$ compared with 5.0 to $11.0 \mathrm{mg} / \mathrm{kg}$ in the undisturbed rainforest (Table 1). The nitrate- $\mathrm{N}$ mean separation analysis indicated no significant difference among the PRF and the mean nitrate- $\mathrm{N}$ was $3.50 \mathrm{mg} / \mathrm{kg}$, which is significantly less than that in the abandoned pasture, $5.5 \mathrm{mg} / \mathrm{kg}$ (Table 2 ). The paired $t$-test indicated the nitrate- $\mathrm{N}$ under rainforest is significantly higher, approximately two to three times, under abandoned pasture or PRF. Ammonium-N content showed trends similar to nitrate-N (Tables 1 and 2). It was highest in the rainforest, $8.6 \mathrm{mg} / \mathrm{kg}$, followed by $5.0 \mathrm{mg} / \mathrm{kg}$ in the abandoned pasture and 3.0 to $4.0 \mathrm{mg} / \mathrm{kg}$ in PRF (Table 2). No significant differences existed among PRF for total $\mathrm{N}$ and it was significantly higher in rainforest and the abandoned pasture. Exclusive of the total $\mathrm{N}$, the other forms of $\mathrm{N}$ under rainforest were higher than the abandoned pasture or PRF.

Because $\mathrm{N}$ is a key plant elemental nutrient, it deserves special attention in our discussion. Nitrateand ammonium-N are the readily and easily available forms of $\mathrm{N}$ in soil for root uptake. Ammonium-N can be adsorbed at cation exchange sites, which increases with increasing soil organic C. Thus, higher ammo- 
Table 1

Ranges in values of the selected soil properties

\begin{tabular}{|c|c|c|c|c|c|c|}
\hline \multirow[t]{2}{*}{ Soil property } & \multicolumn{5}{|l|}{ Treatments } & \multirow[t]{2}{*}{ Rainforest } \\
\hline & Treatment 1 & Treatment 2 & Treatment 3 & Treatment 4 & Treatment 5 & \\
\hline Nitrate-N (mg/kg) & $3.0-4.0$ & $3.0-4.0$ & $3.0-4.0$ & $3.0-4.0$ & $4.0-7.0$ & $5.0-11.0$ \\
\hline Ammonium-N (mg/kg) & $3.0-5.0$ & $4.0-4.0$ & $3.0-3.0$ & $4.0-4.0$ & $5.0-5.0$ & $7.0-11.0$ \\
\hline Total N (g/100 g) & $0.13-0.16$ & $0.15-0.16$ & $0.10-0.18$ & $0.09-0.16$ & $0.18-0.21$ & $0.13-0.26$ \\
\hline Electrical conductivity $(\mathrm{dS} / \mathrm{m})$ & $0.024-0.029$ & $0.027-0.029$ & $0.028-0.029$ & $0.031-0.033$ & $0.032-0.046$ & $0.044-0.081$ \\
\hline $\mathrm{pH}\left(\right.$ in $\left.\mathrm{H}_{2} \mathrm{O}\right)$ & $5.5-5.6$ & $5.4-5.5$ & $5.2-5.4$ & $5.2-5.2$ & $5.4-5.7$ & $4.9-6.0$ \\
\hline $\mathrm{pH}\left(\right.$ in $\left.\mathrm{CaCl}_{2}\right)$ & $4.7-4.7$ & $4.6-4.7$ & $4.4-4.7$ & $4.5-4.5$ & $4.7-4.9$ & $4.3-5.5$ \\
\hline Calcium $(\mathrm{c} \mathrm{mol} / \mathrm{kg})$ & $1.55-1.64$ & $1.53-1.98$ & $1.48-1.69$ & $0.89-1.20$ & $1.47-2.79$ & $0.70-3.82$ \\
\hline Magnesium $\left(\mathrm{c}\right.$ mol $_{\mathrm{c}} / \mathrm{kg}$ ) & $0.70-0.80$ & $0.71-0.93$ & $0.97-1.03$ & $0.54-0.65$ & $0.94-1.41$ & $0.61-1.44$ \\
\hline Sodium $(\mathrm{c} \mathrm{mol} / \mathrm{kg})$ & $0.05-0.10$ & 0.10 & 0.03 & $0.03-0.05$ & $0.03-0.05$ & $0.03-0.13$ \\
\hline Potassium $(\mathrm{c} \mathrm{mol} / \mathrm{cg})$ & $0.20-0.30$ & $0.25-0.26$ & $0.24-0.29$ & $0.15-0.23$ & $0.28-0.45$ & $0.19-0.31$ \\
\hline Aluminum $(\mathrm{c} \mathrm{mol} / \mathrm{cg})$ & $41.60-58.19$ & $40.67-47.65$ & $60.53-96.45$ & $73.33-86.92$ & $27.85-56.92$ & $1.99-15.04$ \\
\hline Total organic $(\mathrm{g} / 100 \mathrm{~g})$ & $2.18-4.00$ & $2.69-2.89$ & $2.39-2.82$ & $1.84-2.75$ & $3.24-4.27$ & $4.82-9.02$ \\
\hline Labile C1 (mg/g) & $4.9-5.3$ & $4.8-4.9$ & $4.8-4.8$ & $4.5-4.9$ & $5.3-5.3$ & $5.9-6.7$ \\
\hline Labile C2 $(\mathrm{mg} / \mathrm{g})$ & $3.8-6.0$ & $2.9-4.2$ & $3.1-3.1$ & $2.2-3.1$ & $4.3-5.6$ & $11.4-16.7$ \\
\hline Bulk density $\left(\mathrm{Mg} / \mathrm{m}^{3}\right)$ & $0.94-1.07$ & $0.85-1.25$ & $0.84-1.21$ & $0.93-1.23$ & $0.94-1.21$ & $0.67-1.14$ \\
\hline Total porosity & $0.65-0.60$ & $0.68-0.53$ & $0.68-0.54$ & $0.65-0.53$ & $0.65-0.54$ & $0.75-0.57$ \\
\hline
\end{tabular}

nium-N indirectly reflects higher total organic $\mathrm{C}$, which is consistent with our results (Table 2). The results in general indicate that even after $\approx 40$ years under abandonment pasture, the accumulation of nitrate- and ammonium-N is not comparable to under rainforest. Significantly low total N under PRF compared with the abandoned pasture suggests that young planted rainforest was probably utilizing the stored $\mathrm{N}$ and/or the inherent difference between the systems before vegetation manipulation.

In general, grassland soils are characterised by higher nitrate- $\mathrm{N}$ than ammonium- $\mathrm{N}$ and an opposite trend is anticipated in forest soils due to high total organic $\mathrm{C}$ as seen in Table 2. Though both nitrate- and ammonium-N were substantially higher in forest soils than in the treatments, including the abandoned pas-

Table 2

Mean values of the selected soil properties and their statistical significance

\begin{tabular}{|c|c|c|c|c|c|c|}
\hline \multirow[t]{2}{*}{ Soil property } & \multicolumn{5}{|c|}{ Treatments } & \multirow[t]{2}{*}{ Rainforest } \\
\hline & TRT 1 & TRT 2 & TRT 3 & TRT 4 & TRT 5 & \\
\hline Nitrate-N (mg/kg) & $3.50 \mathrm{c}$ & $3.50 \mathrm{c}$ & $3.50 \mathrm{c}$ & $3.50 \mathrm{c}$ & $5.50 \mathrm{~b}$ & $8.67 \mathrm{a}$ \\
\hline Ammonium-N (mg/kg) & $4.00 \mathrm{~b}$ & $4.00 \mathrm{~b}$ & $3.00 \mathrm{c}$ & $4.00 \mathrm{~b}$ & $5.00 \mathrm{~b}$ & $8.61 \mathrm{a}$ \\
\hline Total N (mg/kg) & $1450 \mathrm{~b}$ & $1550 \mathrm{~b}$ & $1400 \mathrm{~b}$ & $1250 \mathrm{~b}$ & $1970 \mathrm{a}$ & $1890 \mathrm{a}$ \\
\hline Electrical conductivity $(\mathrm{dS} / \mathrm{m})$ & $0.026 \mathrm{c}$ & $0.028 \mathrm{c}$ & $0.028 \mathrm{c}$ & $0.032 \mathrm{c}$ & $0.039 \mathrm{~b}$ & $0.053 \mathrm{a}$ \\
\hline $\mathrm{pH}\left(\right.$ in $\left.\mathrm{H}_{2} \mathrm{O}\right)$ & $5.55 b$ & $5.45 b$ & $5.35 b$ & $5.20 \mathrm{~b}$ & $5.55 \mathrm{~b}$ & $5.62 \mathrm{a}$ \\
\hline $\mathrm{pH}\left(\right.$ in $\mathrm{CaCl}_{2}$ ) & $4.70 \mathrm{~b}$ & $4.65 b$ & $4.55 b$ & $4.50 \mathrm{~b}$ & $4.80 \mathrm{~b}$ & $5.03 \mathrm{a}$ \\
\hline Calcium $(\mathrm{c} \mathrm{mol} / \mathrm{kg})$ & $1.23 \mathrm{c}$ & $1.76 \mathrm{c}$ & $1.55 \mathrm{c}$ & $1.50 \mathrm{c}$ & $2.13 b$ & $2.51 \mathrm{a}$ \\
\hline Magnesium $\left(\mathrm{c}\right.$ mol $_{\mathrm{c}} / \mathrm{kg}$ ) & $0.75 \mathrm{c}$ & $0.82 \mathrm{c}$ & $1.02 \mathrm{~b}$ & $0.60 \mathrm{c}$ & $1.18 \mathrm{~b}$ & $1.12 \mathrm{~b}$ \\
\hline Sodium $(\mathrm{c} \mathrm{mol} / \mathrm{kg})$ & $0.090 \mathrm{a}$ & $0.065 b$ & $0.025 \mathrm{c}$ & $0.040 \mathrm{c}$ & $0.040 \mathrm{c}$ & $0.052 \mathrm{c}$ \\
\hline Potassium $(\mathrm{c} \mathrm{mol} / \mathrm{c} / \mathrm{kg})$ & $0.25 \mathrm{a}$ & $0.25 \mathrm{a}$ & $0.26 \mathrm{a}$ & $0.19 \mathrm{~b}$ & $0.36 \mathrm{a}$ & $0.23 b$ \\
\hline Sum of $\mathrm{Ca}, \mathrm{Mg}, \mathrm{Na}, \mathrm{K}(\mathrm{c} \mathrm{mol} / \mathrm{kg})$ & $2.32 \mathrm{~b}$ & $2.90 \mathrm{~b}$ & $2.86 \mathrm{~b}$ & $2.33 b$ & $3.71 \mathrm{a}$ & $3.91 \mathrm{a}$ \\
\hline Aluminum $(\mathrm{c} \mathrm{mol} / \mathrm{cg})$ & $49.89 b$ & $44.16 b$ & $78.49 \mathrm{a}$ & $80.15 a$ & $42.38 b$ & $8.51 \mathrm{c}$ \\
\hline Total organic $\mathrm{C}(\mathrm{mg} / \mathrm{kg})$ & $30,900 \mathrm{c}$ & $27,900 \mathrm{c}$ & $26,000 \mathrm{c}$ & $23,000 \mathrm{c}$ & $37,600 \mathrm{~b}$ & $74,800 \mathrm{a}$ \\
\hline Labile C1 (mg/kg) & $5090 \mathrm{~b}$ & $4850 \mathrm{~b}$ & $4820 b$ & $4720 b$ & $5290 \mathrm{~b}$ & $6340 \mathrm{a}$ \\
\hline Labile C2 (mg/kg) & $4900 \mathrm{~b}$ & $3520 b$ & $3060 \mathrm{~b}$ & $2650 \mathrm{~b}$ & $4950 \mathrm{~b}$ & $14,380 \mathrm{a}$ \\
\hline Bulk density $\left(\mathrm{Mg} / \mathrm{m}^{3}\right)$ & $1.00 \mathrm{~b}$ & $1.09 \mathrm{~b}$ & $1.07 \mathrm{~b}$ & $1.11 \mathrm{c}$ & $1.09 \mathrm{~b}$ & $0.93 \mathrm{a}$ \\
\hline
\end{tabular}


ture, no apparent difference existed between these two forms of $\mathrm{N}$ either under the rainforest or abandoned pasture or PRF. The nitrate- plus ammonium-N in the forest soil is $17.28 \mathrm{mg} / \mathrm{kg}$ compared to $5.3 \mathrm{mg} / \mathrm{kg}$ under the abandoned pasture and $3.6 \mathrm{mg} / \mathrm{kg}$ in PRF. There are at least two important aspects that deserve attention here. First, that even after $\approx 40$ years of nongrazing in the abandoned pasture, the pool of the easily available $\mathrm{N}$ forms has not approached magnitudes comparable to the rainforest. Second, the low levels of easily available $\mathrm{N}$ forms under PRF suggests the young forest species may be utilizing the $\mathrm{N}$ reserves. In the absence of easily available $\mathrm{N}$ data at the time of planting, it is difficult to claim whether the young trees were feeding on the $\mathrm{N}$ reserve. The most important issue, however, is whether the quantity of the readily available $\mathrm{N}$ forms present at the time of pasture abandonment, $\approx 40$ years ago, was a limiting factor in natural reforestation cannot be resolved from this data. However, successful reforestation (PRF) using $\mathrm{N}$-fertilizer and still no natural reforestation in abandoned pasture suggests the easily available $\mathrm{N}$ might have been a limiting factor in natural reforestation.

It could be argued that the nitrate- and ammonium$\mathrm{N}$ in soil could vary temporally and spatially and the differences observed in our study from one sampling may be misleading. However, Reiners et al. (1994) indicated that in tropical environments similar to ours the temporal changes were not significant, though spatial variability could be a factor. Thus, based on Reiners et al. (1994) finding we suggest the data reflect the impact of pasture abandonment and PRF on $\mathrm{N}$ in general and in particular the easily available forms of the $\mathrm{N}$.

\subsection{Soil organic $C$}

In general, the total organic $\mathrm{C}$ (SOC) and the labile forms $(\mathrm{C} 1$ and $\mathrm{C} 2)$ are higher in the rainforest than abandoned pasture or PRF (Table 1). The paired $t$-test indicated significant difference between rainforest and each one of the other treatments for the three forms of C (Table 2). The mean separation analysis indicated no significant differences existed among PRF treatments, but significant difference between the abandoned pasture and PRF. The average SOC under abandoned pasture was $37,600 \mathrm{mg} / \mathrm{kg}$ compared with $26,950 \mathrm{mg} / \mathrm{kg}$ under PRF and 74,800 $\mathrm{mg} / \mathrm{kg}$ in rain- forest. Unfortunately, the SOC data at the time of pasture abandonment are not available. However, higher SOC under abandoned pasture than PRF suggests higher SOC mineralization under PRF than under pasture and/or low leaf litter addition under PRF (Blair et al., 1995).

The SOC acts as an exchange surface for cations and direct source of $\mathrm{N}, \mathrm{P}$, and $\mathrm{S}$ through microbial $\mathrm{C}$ and $\mathrm{N}$-immobilization/mineralization reactions (Rasiah, 1999; Rasiah and Kay, 1999). These reactions primarily involve the easily and readily available forms of $\mathrm{C}$ and $\mathrm{N}$. The labile-C1-pool is significantly higher under rainforest, $6340 \mathrm{mg} / \mathrm{kg}$, than in the other treatments, $4950 \mathrm{mg} / \mathrm{kg}$. Though the SOC and labile$\mathrm{C} 1$ under rainforest are much higher than PRF or the abandoned pasture, the proportion of labile- $\mathrm{C} 1$ in the latter is almost twice (15\%) as that in rainforest (8\%). This suggests the microbial activity was probably higher under PRF and pasture than in rainforest (Blair et al., 1995).

The size of the labile-C2 pool is much larger, $14380 \mathrm{mg} / \mathrm{kg}$, under rainforest than the treatments, $3800 \mathrm{mg} / \mathrm{kg}$ (Table 2). The labile-C2 as a fraction of SOC under rainforest is 0.19 compared with 0.12 in the PRF and this trend is just the opposite of that found for labile-C1. The labile-C2 is relatively less readily available for microbes than the $\mathrm{C} 1$-pool (Blair et al., 1995). The differences in the proportion of labile-C1 and $\mathrm{C} 2$ in relation to SOC may be suggesting the differences in the nature and transformations of $\mathrm{C}$ under different vegetation.

The interrelation involving SOC, labile-C1 and C2 are shown in Fig. 1 to illustrate relative differences and the linear associations (Table 3). The SOC increased with increasing labile-C1 and $\mathrm{C} 2$ and labile-C2 increased with increasing $\mathrm{C} 1$ (Table 3). As mentioned elsewhere in the text, these positive associations provide evidence for the claim that labile- $\mathrm{C} 1$ and $\mathrm{C} 2$ transform to produce $\mathrm{SOC}$ and labile-C1 to $\mathrm{C} 2$. Both nitrate- and ammonium- $\mathrm{N}$ increased with increasing SOC, and nitrate with increasing ammonium (Table 3). The former association suggests increases in nitrate and ammonium-N immobilization with increasing SOC (Blair et al., 1995).

With relatively high rainfall, $1700 \mathrm{~mm} /$ year, and small differences in summer and winter temperatures, the potential for high SOC mineralization to occur under the abandoned pasture system, which returns 


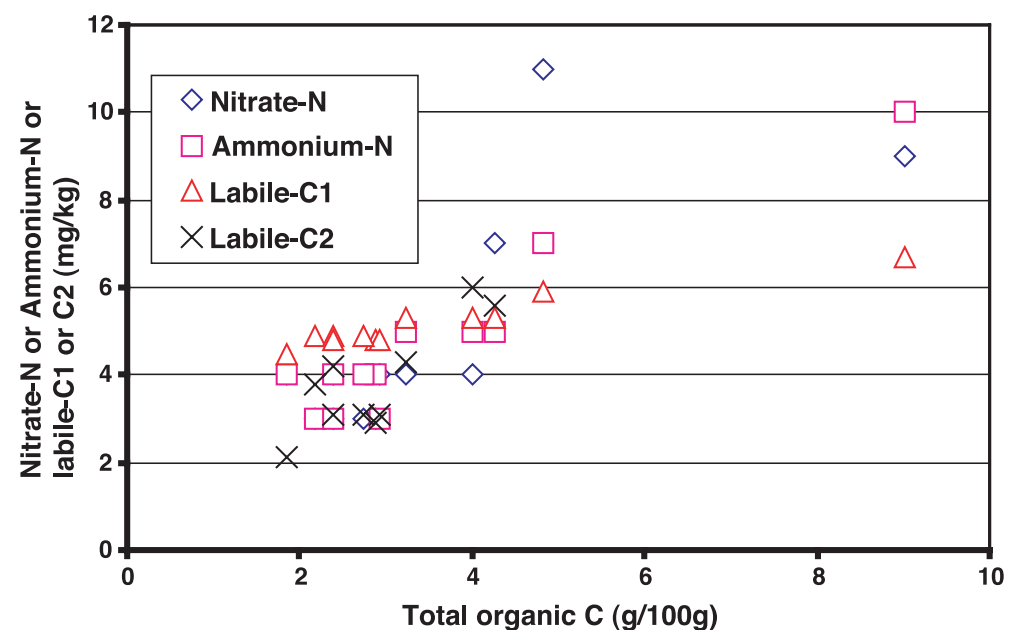

Fig. 1. The relationship among soil organic $\mathrm{C}$, labile-C1, labile-C2, nitrate-N, and ammonium-N.

relatively small quantities of litter to soil, is high. This suggests that $\mathrm{C}$-sequestration in this soil could be slow and the resiliency of the system to return to secondary forest may also be slow (Blair et al., 1995; Berger, 1990).

\subsection{Soil $p H$}

Soil $\mathrm{pH}$ measured, both in water and $\mathrm{CaCl}_{2}$, in general was significantly higher under rainforest than the abandoned pasture or the PRF (Tables 1 and 2). Though the soil was inherently acidic, under rainforest, further acidification of this soil may lead to serious environmental problems including solubilization and leaching of aluminum minerals into water- ways and the natural ecosystem. Increases in soil acidity under cropping, particularly under pasture, is a serious problem that has been associated to decreases in agricultural productivity in this soil type (Moody and Aitken, 1997; Noble et al., 1997; Bolan et al., 1991). It seems that even $\approx 40$ years under abandoned pasture or $\approx 10$ years under planted forest system was not sufficient to, at least, partially ameliorate the soil acidity induced by deforestation.

Increases in soil acidity under cultivation, after deforestation, and particularly under pasture is a common phenomenon (Bolan et al., 1991; Moody and Aitken, 1997; Noble et al., 1997). However, the increases in acidity, compared to rainforest, under abandoned pasture in our study is in contrast to what

Table 3

Correlation matrix for the selected soil properties

\begin{tabular}{|c|c|c|c|c|c|c|c|c|c|c|}
\hline & Ammonium-N & $\begin{array}{l}\text { Total } \\
\mathrm{N}\end{array}$ & SOC & $\begin{array}{l}\text { Labile } \\
\mathrm{C} 1\end{array}$ & $\begin{array}{l}\text { Labile } \\
\mathrm{C} 2\end{array}$ & $\begin{array}{l}\text { Bulk } \\
\text { density }\end{array}$ & Aluminum & $\begin{array}{l}\text { Electrical } \\
\text { conductivity }\end{array}$ & $\begin{array}{l}\mathrm{pH} \\
\left(\mathrm{CaCl}_{2}\right)\end{array}$ & $\begin{array}{l}\text { Exchangeable } \\
\text { bases }\end{array}$ \\
\hline Nitrate-N & +0.98 & +0.93 & +0.99 & +0.98 & +0.97 & ns & -0.84 & +0.97 & +0.96 & +0.96 \\
\hline Ammonium-N & & +0.89 & +0.97 & +0.97 & +0.97 & ns & -0.87 & +0.90 & +0.96 & +0.92 \\
\hline Total N & & & +0.92 & +0.93 & +0.87 & ns & -0.90 & +0.90 & +0.95 & +0.96 \\
\hline SOC & & & & +0.99 & +0.99 & -0.84 & -0.87 & +0.92 & +0.98 & +0.97 \\
\hline Labile C1 & & & & & +0.99 & -0.85 & -0.89 & +0.91 & +0.99 & +0.97 \\
\hline Labile C2 & & & & & & -0.88 & -0.87 & +0.89 & +0.97 & +0.95 \\
\hline Bulk density & & & & & & & ns & ns & -0.83 & ns \\
\hline Aluminum & & & & & & & & ns & -0.94 & -0.88 \\
\hline Electrical conductivity & & & & & & & & & +0.89 & +0.90 \\
\hline $\mathrm{PH}$ & & & & & & & & & & +0.97 \\
\hline
\end{tabular}

ns refers to nonsignificant correlation at $P<0.05$. 
Reiners et al. (1994) reported for the conversion of tropical forest to pasture and subsequent abandonment in the Atlantic Zone of Costa Rica. We are unable to provide any reason for this discrepancy.

The sum of base-exchange cations $(\mathrm{Ca}, \mathrm{Mg}, \mathrm{K}$, and $\mathrm{Na}$ ) or that of the individual cation, exclusive of $\mathrm{K}$, under rainforest, in general, was higher than PRF or the abandonment pasture (Tables 1 and 2). Higher acidity under deforested systems might have favoured solubilization and removal of cations in leaching water. Higher electrical conductivity under rainforest, compared to the other systems, reconfirms larger ion activity, including cations, under rainforest. The positive correlation that exists between $\mathrm{EC}$ and $\mathrm{pH}$ provide evidence for the aforementioned claim (Table 3 ). The PRF spanning only $\approx 10$ years seems to have little impact in ameliorating deforestation-induced loss in base-exchange cation-associated chemical fertility.

In general, the exchangeable $\mathrm{Al}$ under rainforest is less, by an order of magnitude, than the deforested systems (Tables 1 and 2). The Al extraction procedure, oxalic acid/ammonium oxalate, used brought in Al into solution phase that was (i) already in soil solution, (ii) adsorbed at the mineral cation exchange site, and (iii) adsorbed in soil organic matter (Rayment and Higgins, 1992). Significant negative correlations between $\mathrm{Al}$ and the different forms of $\mathrm{C}$, including SOC, suggest that large C-pools in soil reduced the amounts of $\mathrm{Al}$ in solution phase (Table 3). Thus, higher $\mathrm{Al}$, than rainforest, in the abandoned pasture and PRF was at least partially due to low levels of the different forms of soil C. Higher Al under abandoned pasture and PRF could also be attributed to higher acidity and this was supported by the strong negative correlation between $\mathrm{Al}$ and $\mathrm{pH}$ (Table 3). Similar results have been reported by other workers (Adams et al., 2001; Chen et al., 2001). Furthermore, in the absence of any amendment input to neutralize soil acidity, the acidity that developed under grazed pasture for $\approx 30$ years or in the abandoned pasture, $\approx 40$ years, was probably not neutralized. On the other hand, the foliage turnover under rainforest ecosystem was continuously adding exchangeable cations and the possible retention of these cations under high SOC might have created conditions favourable to neutralize acidity in this system. Higher exchangeable cations under rainforest than the deforested systems and the positive correlation that existed between cations and $\mathrm{pH}$ lend support to our claim.

The interrelations involving exchangeable Al, soil $\mathrm{pH}$, exchangeable cations (EXC), labile-C2 are shown in Fig. 2. Though the interaction involving $\mathrm{Al}, \mathrm{pH}$, SOC, and EXC is complex, we tried to explore the relative importance of $\mathrm{pH}$ in water $\left(\mathrm{pH}_{\mathrm{w}}\right), \mathrm{pH}$ in calcium chloride $\left(\mathrm{pH}_{\mathrm{Ca}}\right), \mathrm{SOC}$, labile-C1 (C1) and labile-C2 (C2) on $\mathrm{Al}$ using the stepwise regression procedure. This analysis was conducted to better understand the mechanisms involved in $\mathrm{Al}$ in soil

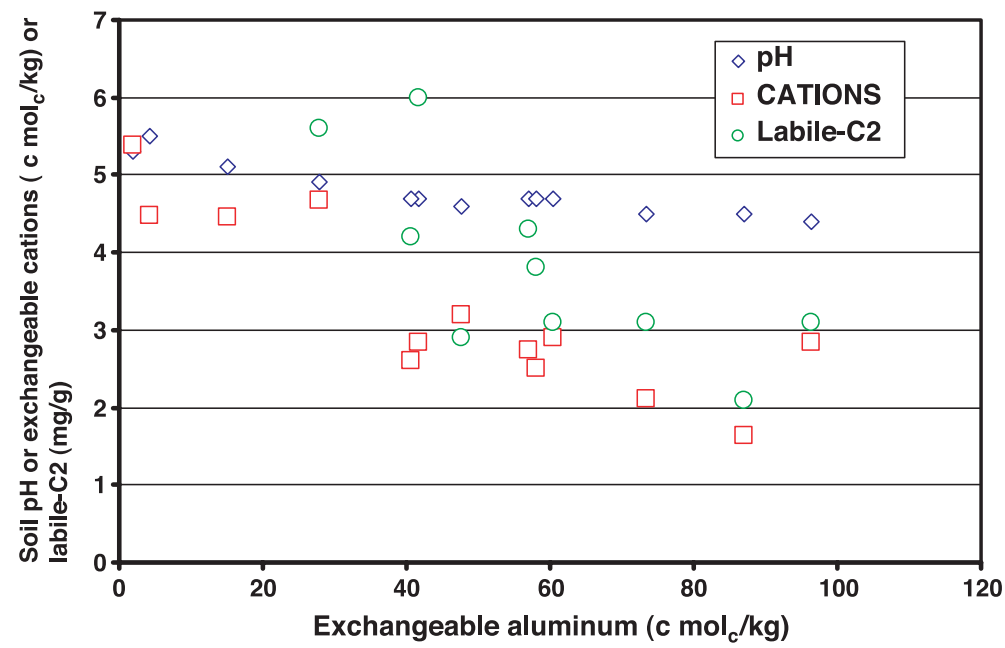

Fig. 2. The relationship between aluminum and $\mathrm{pH}_{\mathrm{CaCl}_{2}}$ or exchangeable cations or labile-C2. 
solution. Further, $\mathrm{Al}$ toxicity is an important issue in this region, and cropping induced acidity, which increase $\mathrm{Al}$ in soil solution, is a reality in this region. In this regard, first we explored $\mathrm{Al}$ as function of $\mathrm{SOC}, \mathrm{C} 1, \mathrm{C} 2, \mathrm{pH}_{\mathrm{w}}, \mathrm{pH}_{\mathrm{Ca}}$, and $\mathrm{EXC}$, and the analysis produced the following equation,

$$
\mathrm{Al}=683.7-\mathrm{pH}_{\mathrm{Ca}} \quad\left(R^{2}=0.81, P<0001\right)
$$

There are at least two important aspects that emerge from Eq. (1). First, the overriding influence of soil acidity on soil solution Al. Second, the $\mathrm{pH}$ determined in $\mathrm{CaCl}_{2}$ is the most appropriate $\mathrm{pH}$ index to quantify the impact on soil solution Al. Because $\mathrm{pH}$ had overriding influence on $\mathrm{Al}$, the impact of the other variables was rejected by the stepwise selection procedure. Thus, we dropped $\mathrm{pH}$ in our second analysis and explored $\mathrm{Al}$ as a function of $\mathrm{SOC}, \mathrm{EXC}, \mathrm{C} 1$ and $\mathrm{C} 2$, and the analysis produced the following equation,

$$
\mathrm{Al}=108.6-12.98 \mathrm{C} 2 \quad\left(R^{2}=0.56, P<0.01\right)
$$

Eq. (2) indicates that $\mathrm{Al}$ in soil solution is controlled by labile-C2 or was immobilized in labile-C2. To explore the cumulative effect of different forms of $\mathrm{C}$, we explored $\mathrm{Al}$ as a function of $\mathrm{SOC}, \mathrm{C} 1$, and $\mathrm{C} 2$ and $\mathrm{EXC}$, and the analysis produced the following equation,

$$
\begin{aligned}
& \mathrm{A} 1+145.3-7.4(\mathrm{SOC}+\mathrm{C} 1+\mathrm{C} 2) \\
& \left(R^{2}=0.56, P<0.02\right)
\end{aligned}
$$

A comparison of the $R^{2}$ values for Eqs. (1) and (2) indicates that there is no advantage gained by including SOC and $\mathrm{C} 1$ in explaining $\mathrm{Al}$ immobilization in soil. The role played by EXC in the absence of $\mathrm{pH}_{\mathrm{Ca}}$ and $\mathrm{C} 2$ was explored by regressing $\mathrm{Al}$ as a function of $\mathrm{EXC}, \mathrm{SOC}$, and $\mathrm{C} 1$, and the analysis produced the following equation,

$$
\mathrm{Al}=116.8-21.0 \mathrm{EXC} \quad\left(R^{2}=0.71, P<0.001\right)
$$

Eq. (4) indicates EXC played a larger role, higher $R^{2}$, than $\mathrm{C} 2$ in reducing potential $\mathrm{Al}$ toxicity. This is anticipated by acidity neutralizing effect through base exchange cations. In the deforested ecosystem under abandoned pasture with little or no external cation input, we believe $\mathrm{C} 2$ played a major role in reducing Al toxicity in such systems.

\subsection{Bulk density and porosity}

The bulk density (BD) under rainforest ranged from 0.67 to $1.14 \mathrm{Mg} / \mathrm{m}^{3}$ compared with 0.85 to $1.21 \mathrm{Mg} / \mathrm{m}^{3}$ in the treatments (Table 1). The average BD under rainforest, $0.93 \mathrm{Mg} / \mathrm{m}^{3}$, was significantly less than the deforested treatments, 1.00 to $1.11 \mathrm{Mg} / \mathrm{m}^{3}$. Exclusive of in one treatment, TRT4, the BDs in the other four treatments were not significantly different from each other. The average total porosity (TP) under rainforest was $0.65 \mathrm{~m}^{3} / \mathrm{m}^{3}$ compared with $0.59 \mathrm{~m}^{3} / \mathrm{m}^{3}$ for the abandoned pasture. Higher BD and lower TP under deforested systems are not very uncommon (Reiners et al., 1994). Conversion from forest to pasture, particularly under cattle, decreases the TP, mostly at the expense of larger pores and the pore continuity, through cattle trampling and other physical/mechanical stresses. With decreases in larger pores, habitable pores of soil mixing arthropod and small animal community would decrease, consequently, their population. The decline in population in this group of soil organisms may further reduce the formation of larger pores (Keller et al., 1993). Reduction in porosity, pore continuity, and pore closure at the surface through trampling could have serious impact on infiltration and percolation. Reductions in infiltration and percolation will favour increases in surface runoff, erosion, and ultimately serious land degradation. Decreases in TP may create conditions favourable for anaerobiosis and reduction in diffusivity, and consequently the production of gases such as $\mathrm{NO}, \mathrm{N}_{2} \mathrm{O}$, and $\mathrm{CH}_{4}$ (Keller et al., 1993). Thus, the impact of deforestation and subsequent pasture production on $\mathrm{BD}$ may lead to significant multiple effects on several soil physical, chemical, and biological processes. Even after $\approx 40$ years of pasture abandonment, the deforested soil seems to have not recovered from deforestation-induced increases in BD. This suggests the resiliency of this soil to regain its physical potential is low.

\section{Conclusions}

Though the land has been under abandoned pasture for a relatively long period ( $\approx 40$ years), insufficient 
improvements, compared to the rainforest, in nitrate$\mathrm{N}$, ammonium- $\mathrm{N}$, total $\mathrm{N}$, total soil organic $\mathrm{C}$, labile$\mathrm{C}$, electrical conductivity, exchangeable cations, exchangeable $\mathrm{Al}$ (high), $\mathrm{pH}$ (i.e. more acidic), bulk density (high), and porosity (low) have occurred during this time frame. This implies the resiliency of this soil in the particular tropical environment to recover from deforestation induced land degradation is low. Because the planted rainforest was in place only for $\approx 10$ years, the recovery from degradation was not expected to be significant. The inability of the soil to recover substantially under relatively long period of abandoned pasture indicates that extreme care should be taken in the management of the deforested lands in similar tropical environments. Very high concentration of exchangeable $\mathrm{Al}, 10$-fold compared to the rainforest, even after $\approx 40$ years under abandoned pasture indicates the ability of the system to immobilize $\mathrm{Al}$ in insoluble forms is very poor. Because Al-induced acidity and/or toxicity is an environmental and production issue in this region, particular attention should be directed to exchangeable $\mathrm{Al}$ dynamics in soil subsequent to deforestation. In general, the results from this study indicate the time frame as long as $\approx 40$ years under abandoned pasture was not sufficient to rehabilitate, at least mid-way between rainforest and cultivated degraded soils in tropical environment similar to the study area.

\section{Acknowledgements}

The authors gratefully acknowledge the financial support and other facilities provided by the School for Field Studies, 16 Broadway, Beverly, MA 01915, USA.

\section{References}

Adams, M.L., Davis, M.R., Powell, W., 2001. Effects of grassland afforestation on exchangeable soil and solution aluminium. Aust. J. Soil Res. 39, 1003-1014.

Aide, T.M., Cavelier, J., 1994. Barriers to tropical lowland forest restoration in the Sierra Nevada de Santa Marta, Colombia. Restor. Ecol. 2, 219-229.

Aide, T.M., Zimmerman, J.K., Herrera, L., Rosario, M., 1995. Forest recovery in abandoned tropical pastures in Puerto Rico. For. Ecol. Manag. 77, 77-88.
Baldock, J.A., Kay, B.D., 1987. Influence of cropping history and chemical pretreatments on the water stable aggregation of a silt loam soil. Can. J. Soil Sci. 67, 501-511.

Berger, J.J., 1990. Environmental Restoration. Island Press, Washington, DC.

Blair, G.J., Lefroy, R.D., Lisle, L., 1995. Soil carbon fractions based on their degree of oxidation, and the development of a carbon management index for agricultural systems. Aust. Agric. Res. 46, 1459-1466.

Bolan, N.S., Hedley, M.J., White, R.E., 1991. Process of soil acidification during nitrogen cycling with emphasis on legume based pastures. Plant Soil 134, 53-63.

Brodie, J., 2003. The Effects of Land Use on Water Quality in Australian Northeast Coastal Catchments. Australian Centre for Tropical Freshwater Research, James Cook University, Townsville, Australia.

Brown, S., Lugo, A.E., 1990. Tropical secondary forests. J. Trop. Ecol. 6, 1-32.

Buschbacher, R., 1986. Tropical deforestation and pasture development. Bioscience 36, 23-27.

Buschbacher, R., Uhl, C., Serrao, E.A.S., 1984. Abandoned pastures in eastern Amazonia: II. Nutrients stock in the soil and vegetation. J. Ecol. 76, 682-699.

Chen, C.R., Condron, L.M., Davis, M.R., Sherlock, R.R., 2001. Effects of land-use change from grassland to forest on soil sulfur and acrylsulfatase activity in New Zealand. Aust. J. Soil Res. 39, 749-757.

Crome, F.H.J., Bentrupperbaumer, J., 1993. Special people, special animal and special vision: the first steps to restoring a fragmented tropical landscape. In: Saunders, D.A., Hobbs, R.J., Ehrlich, P.R. (Eds.), The Reconstruction of Fragmented Ecosystems. Nature Conservation, vol. 3. Surrey Beatty and Sons, Chipping Norton, NSW, pp. 267-279.

Gillman, G.P., Abel, D.J., 1987. A summary of surface charge characteristics of the major soils of the Tully-Innisfail Area, North Queensland. CSIRO Division of Soils, Divisional Report No. 85, Australia.

Gillman, G.P., Sinclair, D.F., 1987. The grouping of soils with similar charge properties as a base for agrotechnology transfer. Aust. J. Soil Res. 25, 275-285.

Goosem, S., Tucker, N., 1995. Repairing the Rainforest: Theory and Practice of Rainforest Re-establishment in North Queensland's Wet Tropics. WTMA, Cairns, QLD.

Hecht, S.B., 1993. The logic of livestock and deforestation in Amazonia. Bioscience 43, 687-695.

Isbell, R.F., 1994. Krasnozems - a profile. Aust. J. Soil Res. 32, 914-929.

Johnston, M.H., 1992. Soil-vegetation relation ships in a tabonuco forest community in the Luquillo Mountains of Puerto Rico. J. Trop. Ecol. 8, 252-263.

Jusoff, K., 1989. Physical soil-properties associated with recreational use of forested reserve area in Malaysia. Environ. Conserv. 16, 339-342.

Keenan, R.J., Hambleton, A., Robson, K., Webb, M., 1998. Growth response of three rainforest cabinet timber to fertiliser application in plantations in North Queensland. In: Schulte, A., Ruhiyat, D. (Eds.), Soils of Tropical Forest Ecosystems: 
Characteristics, Ecology and Management. Springer, Berlin, pp. $107-114$.

Keller, M., Veldkamp, E., Weitz, A.M., Reiners, W.A., 1993. Effects of pasture age on soil trace-gas emissions from a deforested area of Costa Rica. Nature 365, 244-246.

Kiese, K., Papen, H., Zumbusch, E., Butterbach-Bahl, L., 2002. Nitrification activity in tropical rainforest soils of the coastal lowlands and Atherton Tablelands, Queensland, Australia. J. Plant Nutr. 165, 682-685.

Lu, D., Moran, E., Mausel, P., 2002. Linking Amazonian secondary succession forest growth to soil properties. Land Degrad. Dev. 13, 331-343.

Maggs, J., Hewett, B., 1990. Soil and litter respiration in rainforest of contrasting nutrients status and physiognomic structure near Lake Eacham, northeast Queensland. Aust. J. Ecol. $15,320-336$.

Maggs, J., Hewett, B., 1993. Organic C and nutrients in surface soil from some primary rainforests, derived grasslands and secondary rainforest on the Atherton Tableland in North East Queensland. Aust. J. Soil Res. 31, 343-350.

Moody, P.W., Aitken, R.L., 1997. Soil acidification under some tropical systems: 1. Rates of acidification and contributing factors. Aust. J. Soil Res. 35, 163-173.

Murtha, G.G., 1986. Soils of the Tully-Innisfail area, North Queensland. CSIRO Division of Soils, Divisional report N0. 82, Australia.

Noble, A.D., Cannon, M., Muller, D., 1997. Evidence of accelerated soil acidification under Stylosanthes- dominated pastures. Aust. J. Soil Res. 35, 1309-1322.

Productive Commission, 2003. Industries, Land Use and Water Quality in the Great Barrier Reef Catchment, Research Report, Canberra. Media Publications, Victoria. Australia. ISBN 1 740371135.

Rasiah, V., 1999. Temporal dynamics of soil nitrate-N after termination of forage phases in corn-forage rotation. Biol. Fertil. Soils 29, 201-206.

Rasiah, V., Kay, B.D., 1999. Temporal dynamics of microbial biomass and mineral-N in legume amended soils from a spatially variable landscape. Geoderma. 92, 239-256.

Rasiah, V., Kay, B.D., 1994a. Quantifying the changes in clay stabilization after the introduction of forages. Soil Sci. 157 (5), 318-326.

Rasiah, V., Kay, B.D., 1994b. Characterizing the changes in aggre- gate stability subsequent to introduction of forages. Soil Sci. Soc. Am. J. 58, 935-942.

Rasiah, V., Kay, B.D., 1995. Runoff and soil loss as influenced by selected stability parameters and cropping and tillage practices. Geoderma 68, 321-329.

Rayment, G.R., Higgins, F.R., 1992. Australian Laboratory Handbook of Soil and Water Chemical Methods. Inkata Press, Sydney.

Reiners, W.A., Bouwman, A.F., Parson, W.F.J., Keller, M., 1994. Tropical rainforest conservation to pasture: changes in vegetation and soil properties. Ecol. Appl. 4, 363-377.

Sahani, U., Behera, N., 2001. Impact of deforestation on soil physicochemical characteristics, microbial biomass and microbial activity of tropical soil. Land Degrad. Dev. 12, 93-105.

SAS, 1991. SAS/STAT Procedure Guide for Personal Computers. Version 5. Statistical Analysis Systems Institute, Cary, NC.

Searle, P.L., 1984. Analyst 109, 549-568.

Sparling, G.P., Hart, P.B.S., August, J.A., Leslie, D.M., 1994. A comparison of soil and microbial carbon, nitrogen and phosphorus contents, and macro aggregate stability of a soil under native forest and after clearance for pastures and plantation forest. Biol. Fertil. Soils 17, 91-100.

Tisadall, J.M., Oades, J.M., 1980. The management of ryegrass to stabilize aggregates in a red-brown earth. Aust. J. Soil Res. 18, $415-422$.

Tracey, J.G., 1982. The Vegetation of Humid Tropics of North Queensland. CSIRO, Melbourne, Australia.

Tucker, N.I.J., 2000. Linkage restoration: interpreting fragmentation theory for the design of a rainforest linkage in the humid Wet Tropics of northeast Queensland. Eco. Manag. Rest. 1, $35-39$.

Tucker, N.I.J., Murphy, T.M., 1997. The effect of ecological rehabilitation of vegetation recruitment: some observations from the wet tropics of north Queensland. J. For. Ecol. Manag. 99, $133-152$.

Uhl, C., 1987. Factors controlling succession following slash andburnt agriculture in Amazonia. J. Ecol. 75, 377-407.

Uhl, C., Buschbacher, R., Serrao, E.A.S., 1988. Abandoned pastures in eastern Amazonia: 1. Patterns of plant succession. J. Ecol. 73, $663-681$.

Webb, M.J., Reddell, P., Hambleton, A., Mazza, G.M., 1997. Nutritional constraints to growth of Australian red cedar (Toona ciliata) in five north Queensland soils. Aust. For. 60, 46-62. 